\title{
CLASSIFICATION OF THE GALL-WASPS AND THE PARASITIC CYNIPOIDS, OR THE SUPERFAMILY CYNIPOIDEA. II.
}

By William H. AShmead, A. M., assistant CURator, U. S. national museum.

Subfamily IV. - Liopterinae.

I 894. Liopterinae, Subfamily IV, Ashmead, Proc. ent. soc. Washington, vol. 3, p. I 7 .

This group was first recognized as a subfamily by the writer about ten years ago, and I am surprised therefore, to see that Dr. von Dalla Torre takes credit for it in Wytsman's Genera Insectorum, Family Cynipidae, received January 27, r903. $\mathrm{He}$, and some other writers, placed the group in the subfamily AnacharinaE, but its resemblance to that subfamily is merely superficial, the attachment of the abdomen, the abdomen itself, and the antennae being quite different.

In the publication quoted above I suggested that the group was probably an ancient phylum of the Cynipidae whence originated some of the Chalcidoidea, Chalcis, Eurytoma, etc. Since the suggestion was made additional evidence supporting it has been found in the African genus OberTHÜRELla Saussure, occurring in Madagascar and Liberia, a genus belonging to this group, not mentioned by Dalla Torre or by Kieffer, and which has the hind femora slightly swollen and armed with a tooth beneath, similar to some chalcidoids.

\section{Table of Genera.}

1. Head and thorax coarsely rugose; marginal cell closed

Scutellum normal, not ending in a spine; hind femora unarmed . 2 Scutellum ending in a long, acute spine; hind femora armed with a strong tooth beneath, before the middle; $q$ antennae I3-jointed, $\delta$ I4jointed. (Africa.) . . . . . . Oberthürella Saussure.

(Type O. lenticularis Sauss.)

2. Discoidal nervure interstitial with the median nervure; $q$ antennae $\mathbf{I} 3$-jointed, $\delta$ I 4-jointed . . . . . . . . . . . . . . . Liopteron Perty. (Type L. compressum Perty.) Discoidal nervure not interstitial with the median nervure but issuing from the transverse median nervure; $\$$ unknown, $\delta$ antennae I3-jointed, clavate Peras Westwood. (Type P. niger Westw.) 


\section{Subfamily V. - Eucoilinae.}

I86r. Eucoilidae, Familia, Thomson, Öfvers. vet. akad. forhl. no. 9, p. 397. 1869. Eucoeloidae, Familie 4, Förster, Verh. zool.-bot gesell. Wien, vol. I9, p. $329,34 \mathrm{r}$.

This group is without doubt the largest and most widely distributed of any in the family Figitidae, the genera and species being exceedingly numerous although but little studied. As soon as the attention of entomologists is directed to the collecting of these obscure wasps and especially in tropical countries we may expect the discovery of many new genera, as is clearly shown by the new genera described here, most of which were recognized in a small collection of these insects taken by Mr. Herbert H. Smith in South America.

The subfamily is at once recognized by the cup-like elevation on the scutellum and by the hind tibiae having two apical spurs, characters not found in any other group.

\section{TABle of Genera.}

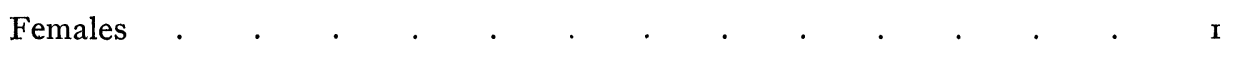

Males . . . . . . . . . . . . . $6 \mathrm{r}$

I. Metathorax normal, not produced, the abdomen at most subsessile - (Tribe II Eucoilinae.) ..$\quad$. $\quad . \quad$. . . . . . . . 3

Metathorax produced into a long neck, the length of the hind coxae, the abdomen abnormally petiolated, the petiole being long and slender, longer than the thorax. (Tribe I. Zamischini.) . . . . . . . . 2

2. Body of abdomen not large, compressed; $q$ antennae long, r3-jointed, thickened toward apex, slender basally, the third joint shorter than the fourth. (Brazil.)

Zamischus Ashmead, gen. nov.

(Type Z. brasiliensis Ashm.)

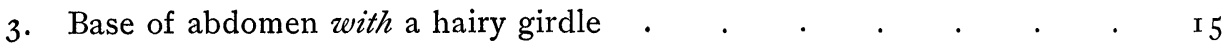

Base of abdomen bare, without a hairy girdle

Mesonotum with parapsidal furrows . . . . . . . 44

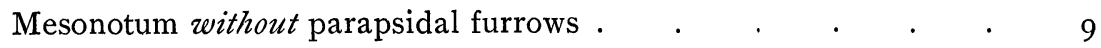

4. Parapsidal furrows distinct to base of scutellum . . . . . . 5 Parapsidal furrows not distinct to base of scutellum, converging and meeting before reaching the scutellum, thence to base of scutellum as a delicate carina; cup of scutellum large, marginal cell closed; antennae I3-jointed

Eucoilidia Ashmead

(Type E. canadensis Ashm.) 
5. Parapsidal furrows converging and meeting at the base of the scutellum 6 Parapsidal furrows almost parallel, or some distance apart to the base of the scutellum

6. Marginal cell closed along the front margin

Gronotoma Förster

Marginal cell open along the front margin

(Type G. sculpturata Först.)

Marginal cell open along the front margin

(Type D. eupatorii Först.)

7. Marginal cell open along the front margin

Marginal cell closed along the front margin

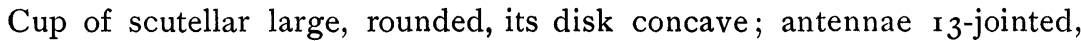
long, subfiliform, only slightly and gradually thickened towards apex

Microstilba Förster

(Type M. bidentata Förster)

8. Mesonotum with five carinae; cup of scutellum large, oval or rounded; antennae I3-jointed, filiform, joints 4-I 2 long oval. (South America.)

Tropideucoela Ashm., gen. nov.

(Type T. rufipes Ashm.)

Mesonotum without carinae; cup of scutellum large; antennae r 3-jointed, without a distinct club

Disorygma Förster

(Type D. divulgata Först.)

9. Marginal cell open along the front margin . . . . . . . . . $\quad$ ro

Marginal cell closed along the front margin . . . . . . . . . $\quad$ I3

ı。. Scutellum normal, unarmed _.

Scutellum abnormal, armed with two horns behind

Antennae 13 -jointed, ending in a 6-jointed club

Dicerataspis Ashmead

(Type D. grenadensis Ashm.)

I I. Antennae ending in an abrupt club, which is three or more jointed . I 2 Antennae at most subclavate, without a distinct, abrupt club

Ectolyta Förster ('Type Cothonaspis incressata Thoms.)

12. Club of antennae 3-jointed . . . . . . . Triplasta Kieffer (Type Kleidotoma atrocoxalis Ashm.) Cup of antennae 5-jointed $\quad . \quad$. $\quad . \quad$. $\quad . \quad$ Pentaplasta Kieffer (Type Pentacrita coxalis Ashm.)

r3. Antennae ending in a distinct, abrupt club . . . . . . . . $\quad$ I 4 Antennae without a distinct club . . . Erisphagia Förster (Type Eucoila curta Gir.) 
14. Club of antennae 5-jointed (rarely 6-jointed)

Apex of front wings entire

Psilosema Kieffer = Cothonaspis Thomson Förster

(Type C. pentatoma Thoms.)

Apex of front wings emarginate or excised . . Schizosema Kieffer

(Type Eucoila emarginata Hartig.)

I5. Front wings at apex emarginate or excised; apical abscissa of the submarginal vein stout, quadrate, at the most only a little longer than thick . . . . I6

Front wings at apex entire, never emarginate or excised although sometimes shortened and truncate; apical abscissa of the submarginal vein slender, not stout, always two or more times longer than thick . . . . $\quad{ }_{2} 3$

r6. Marginal cell open along the front margin . . . . . . . . $\quad$ I 7

Marginal cell closed along the front margin

Club of antennae 6- or 7-jointed . . . . L Leptopelina Förster (Type Eucoila longipes Hartig.)

17. Antennae ending in a distinct, abrupt club . . . . . . . $\quad$. 18 Antennae filiform or subfiliform, not ending in a distinct club

Arhoptra Kieffer (Type Eucoila melanopoda Cam.)

r8. Club of antennae more than 3 -jointed . . . . . . 20 Club of antennae 3 -jointed

Scutellum normal, not produced into a beak at apex . . . $\quad$ I9 Scutellum abnormal, produced into a beak or horn at apex; funicle joints 2-7 small, moniliform _ . . . . . Rhynchacis Förster (Type Cothonaspis niger Hartig.)

19. Wings extending far beyond tip of abdomen . . Kleidotoma Westwood $=$ Trirhoptrasema Kieffer ${ }^{1}$ (Type K. psiloides Westw.)

20. Club of antennae more than 4 -jointed Club of antennae 4-jointed Tetrarhoptra Förster ('Type T. tetratoma Först.)

21. Club of antennae more than 5 -jointed 22 Club of antennae 5 -jointed Pentacrita Förster (Type Eucoila cordata Gir.)

22. Club of antennae 6-jointed Hexacola Förster ('Type Kleidotoma hexatoma Thoms. = Hexacola picea Först.)

\footnotetext{
1 Kieffer proposes this genus for my Kleidotoma americana, which, however, is a true Kleidotoma. I am probably responsible for the Abté's error by describing through a lapsus pennae the marginal cell as being closed, when it is really more or less open along the fore margin.
} 
Club of antennae 7 -jointed $\quad . \quad$. . . . Heptameris Förster (Type Eucoila pygmea Thoms.)

23. Wings abbreviated and much narrowed . . . . . $\quad 24$ Wings not abbreviated, fully developed and always extending far beyond the tip of the abdomen . . . . . . . . . . . 28

24. Club of antennae less than 7 -jointed . . . . . . . . . $\quad 25$ Club of antennae 7 -jointed . . . . . . Nedinoptera Förster (Type Eucoila holophila Thomson)

25. Metapleura bare, without a hairy cushion . . . . . . 26 Metapleura covered with a hairy cushion

Marginal cell not fully developed, the first abscissa of the radius alone present, or longer than the second when the latter is present

Glauraspidia Thomson (Type G. parva Thomson.) Marginal cell fully developed, the first abscissa of the radius shorter than the second

Apistophyza Förster (Type Eucoila microptera Hartig.) 26. Wings extending at least to the middle of the abdomen, and usually with a

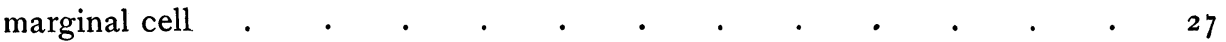

Wings not extending beyond the base of the abdomen, and without a marginal cell; club of antennae 3-jointed . . . . Aphyoptera Förster (Type A. inustipennis Förster)

27. Wings shorter than the abdomen, the marginal cell closed

Agroscopa Förster (Type A. helgolandica Först.) Wings as long as the abdomen, the marginal cell present but open along the front margin; club of antennae 5-jointed . . . Aphiloptera Förster (Type A. anisomera Först.)

28. Antennae I I-, I 2-, or I3-jointed . . . . . . . . . 29 Antennae 14-jointed

Wings bare, glabrous . . . . Macrocereucoila Ashmead

Wings pubescent ciliate (Type M. longicornis Ashm.)

Antennae filiform, without a distinct club, the third joint longer than the fourth . . . . . . . . Episoda Förster (Type E. xanthoneura Först.) 29. Antennae I I-jointed, filiform (South America.) Promiomoera Ashm., gen. nov. (Type P. filicornis Ashm.)

Antennae 12-or 13-jointed 
Antennae r 2-jointed . . . . . . . . . . 30

Antennae I3-jointed . . . . . . . . . . . 32

30. Marginal cell closed along the front margin . . . . . $3^{\mathbf{r}}$ Marginal cell open along the front margin . . Idiomorpha Förster

('Type I. melanocera Först.)

3 I. Cup of scutellum large, rounded, the whole disk impressed or concave; antennae filiform, the third joint the longest, or without an abruptly defined club

Miomoera Förster

(Type M. aberrans Först.)

Cup of scutellum large oval, the whole disk not impressed, anteriorly flat, posteriorly with a fovea, with small punctures bordering the margin; antennae ending in an abrupt 7 -jointed club . . Paramiomoera Ashmead

(Type P. heptoma Ashm.)

32. Marginal cell closed along the front margin . . . . . . 33.

Marginal cell open along the front margin . . . . . . 50

33. Wings pubescent, the margins fringed or ciliated . . . . . $\quad$. 34

Wings bare, glabrous, not pubescent or ciliated

Antennae subfiliform not ending in a distinct club, although slightly thickened toward apex, the third joint a little longer than the fourth

Eucoila Westwood. = Psilodora Förster

(Type E. crassinervis Westw.)

34. Abdomen not unusually compressed, the hypopygium not prominent; second joint of the flagellum usually shorter than the first, rarely as long or a little longer $\quad 3^{6}$ Abdomen usually strongly compressed at the sides, the hypopygium most frequently prominent, plow-share shaped; second joint of the flagellum always distinctly longer than the first.

Scutellum ending in a spine $\quad . \quad$. $\quad . \quad$. $\quad . \quad 35$

Scutellum normal

Antennae long, without a distinct club . Hypolethria Förster

(Type Cothonaspis melanoptera Hartig.)

35. Antennae long, gradually thickened toward apex, the third joint only about two thirds the length of the fourth, 4 to 6 long, cylindrical (South America.)

Odonteucoila Ashmead, gen. nov. (Type O. chapadae Ashm.)

36. Scutellum not ending in a spine $\quad . \quad+\quad . \quad . \quad . \quad . \quad 37$ Scutellum ending in a spine

Antennae long, gradually thickened towards apex, the third joint much shorter than the fourth

Odontoeucoila Ashmead 
37. Flagellar joints all long and cylindrical, the last 7 or 8 joints, however, are sometimes stouter and form sometimes a more or less well defined club; first abscissa of the radius distinctly shorter than the second . . . . 38

Flagellar joints not all long and cylindrical, some oblong oval, ellipzoidal, or moniliform

38. Scutellum normal, the cup not modified into a carina $\quad$. $\quad 39$

Scutellum abnormal, the axillae acutely toothed posteriorly, the cup modified into a carina which is gradually dilated posteriorly, appearing tridentate; antennae long, filiform, the flagellar joints long, cylindrical, the first joint of the flagellum not quite so long as the second (South America.)

Trissodontaspis Ashmead, gen. nov. (Type T. rufipes Ashm.)

39. Head and thorax finely coriaceous, not polished, the scutellum with two large oblong foveae at base, the cup narrowed ellipzoidal, connected with a carina anteriorly; antennae long, subfiliform slightly and gradually thickened toward apex, the flagellar joints long, cylindrical, the first shorter than the second, third, or fourth which are about equal, the fifth and beyond a little thicker and shorter. (South America.)

Dieucoela Ashmead, gen. nov.

(Type D. subopaca Ashm.)

Head and thorax smooth, shining, the scutellum with a large oval or round cup; first three joints of flagellum much elongated, and slenderer than the following . . . . . . . . . . . . Aglaotoma Förster (Type Cothonaspis codrunus Först.)

40. Mesonotum without furrows or lines . . . . . . . . 4 I

Mesonotum with furrows or grooved lines.

Marginal cell rather short and broad, the second abscissa of the radius curved

Chrestosema Förster (Type C. erythrapum Först.)

4I. Cup of scutellum excavated, smooth in front, the anterior part closed, poste-

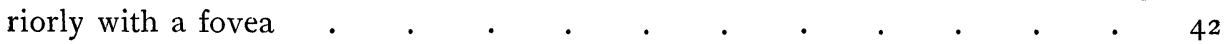

Cup of scutellum flattened, neither excavated nor margined, slightly arched; metathorax smooth; antennae filiform . . . Ganaspis Förster

(Type G. mundata Först.)

42. Cup of scutellum not extending over the tip of the scutellum; antennae

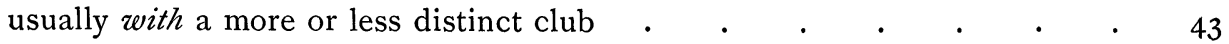

Cup of scutellum greatly elevated above the tip of the scutellum; antennae without a distinct club, usually long . . . . . . Psichara Förster

(Type Cothonaspis longicornis Hartig.) 43. First and second abscissae of the radius not nearly equal in length, the first most frequently much shorter than the second . . . . . . 44 
First and second abscissae of the radius equal in length or very nearly

Antennae usually with a 7- or 8-jointed club, the joints elongate, cylindrical, the first joint of the flagellum shorter than the second; cup of scutellum usually small . . . . . . Rhoptromeris Förster (Type Cothonaspis eucera Hartig.)

44. Marginal cell not short, much longer than wide

Marginal cell rather short, hardly longer than wide, the second abscissa of the radius curved outwardly (South America.)

Zaeucoela Ashmead, gen. nov. (Type Z. unicarinata Ashm.)

45. Antennae with an abruptly defined club; cup of scutellum usually small, narrowed, ovate or ellipzoidal, rarely large oval . . . . . . . . . . ${ }_{4}{ }_{4} 6$ Antennae without an abruptly defined club, filiform or nearly, or only slightly, incrassated toward apex . . . Pseudoeucoila Ashmead, gen. nov.

$=$ Eucoila Auctore.

(Type Cothonaspis trichopsila Hartig.)

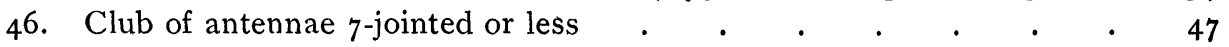
Club of antennae 8-jointed.

Flagellum with joints 2 and 3 very small, together scarcely as long as the first

Dimicrostrophis Ashmead (Type D. ruficornis Ashm.)

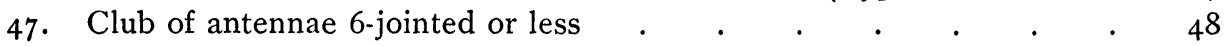
Club of antennae 7 -jointed.

Flagellum with joints 2 and 3 not small, neither much shorter than the first

Heptamerocera Ashmead (Type H. robusta Ashm.)

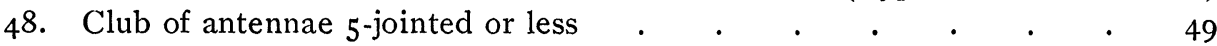
Club of antennae 6-jointed . . . . . . Hexamerocera Kieffer (Type Eucoila rufiventris Gir.)

49. Club of antennae 5 -jointed

Pentamerocera Ashmead. (Type P. angularis Ashm.)

Club of antennae 4 -jointed

Tetramerocera Ashmead

(Type T. variabilis Ashm.)

50. Marginal cell closed at base, the apical abscissa of the submarginal vein distinct

Marginal cell open at base or confluent with the costal cell, the apical abscissa of the submarginal vein wanting

Second abscissa of the radius usually wanting or much abbreviated; scutellum at apex normal Adieris Förster (Type A. reclusa Först.) 
Second abscissa of the radius distinct; scutellum at apex usually emarginate and obtusely bidentate .

Piezobria Förster (Type P. bicuspidata Först.)

5I. Wings pubescent, ciliate

Wings bare, glabrous, not ciliate.

Antennae 13-jointed . . . . . . . Lytosema Kieffer ('Type Eucoila guérinii Dahlb.)

52. Abdomen not unusually compressed, the hypopygium not very prominent 53 Abdomen much compressed, the hypopygium prominent plow-share shaped; antennae long, subfiliform, the joints elongate; cup of scutellum narrowed, ellipzoidal; cubitus in front wings more or less distinct Pilinothrix Förster (Type P. designata Först.)

53. Front wings with the cubitus wanting . . . . . . . 54 Front wings with the cubitus present, distinct

Antennae filiform, without a distinct club . . Anectoclis Förster ('Type A. indagatrix Först.) Antennae subclavate or clavate more or less thickened toward apex, the joints submoniliform Cothonaspis Hartig = Trybliographa Förster (Type Cothonaspis scutellaris Hartig.)

54. Cup of scutellum normal, not ending in a spine . . . . . 55 Cup of scutellum abnormal, ending in a long spine

Acantheucoela Ashmead (Type Cynips armatus Cresson.)

55. Cup of scutellum not large . . . . . . . . . . . $\quad . \quad{ }_{56}^{6}$ Cup of scutellum large oval or rounded

Antennae clavate, the club not abruptly defined but more than 6jointed

Diranchis Förster (Type D. copulata Först.)

56. Club of antennae distinct, abruptly defined, $3^{\text {- to }} 7$-jointed . $\quad . \quad 57$ Club of antennae not abruptly defined; cup of scutellum small, narrowed ellipzoidal; first two joints of flagellum very slender, shorter than the following

Hypodiranchis Ashmead (Type H. hawaiiensis Ashm.)

57. Club of antennae 6-jointed or less Club of antennae 7 -jointed Heptaplasta Kieffer (Type Heptamerocera aliena Ashm.)

58. Club of antennae 5-jointed or less 
Club of antennae 6-jointed

Hexaplasta Förster $=$ Didyctium Riley

(Type Cothonaspis hexatoma Hartig.)

59. Club of antennae 4-jointed or less Club of antennae 5-jointed

6o. Club of antennae 4 -jointed Pentarhoptra Kieffer (Type Eucoila tomentosa Giraud) Tetraplasta Ashm., gen. nov. (Type T. unica Ashm.)

Club of antennae 3 -jointed

Eutrias Förster

6r. Metathorax produced into a long neck the length of the hind coxae, the abdomen abnormally petiolated, the petiole long and slender, longer than the thorax

Zamischus Ashm.

Metathorax normal not produced, the abdomen subsessile.

Abdomen at base bare, without a hairy girdle . . . . 62

Abdomen at base with a hairy girdle . . . . . . 73

62. Mesonotum with parapsidal furrows . . . . . . . . . . $\quad 63$

Mesonotum without parapsidal furrows . . . . . . . . . 68

63. Parapsidal furrows distinct to base of scutellum . . . . . $\quad 64$

Parapsidal furrows not distinct to base of scutellum, converging and meeting before reaching the base of the scutellum, thence to base as a delicate carina; marginal cell closed; antennae $\mathrm{r}_{5}$-jointed . . Eucoilidea Ashmead

64. Parapsidal furrows converging and meeting at the base of the scutellum $6_{5}$ Parapsidal furrows almost parallel or some distance apart to the base of the scutellum

65. Marginal cell closed along the front margin; cup of scutellum large; antennae I 5 -jointed, the first flagellar joint longer than the second, excised towards base

Gronotoma Förster

Marginal cell open along the front margin ; antennae I $_{5}$-jointed

Diglyphosema Förster

66. Marginal cell open along the front margin

Marginal cell closed along the front margin

Cup of scutellum large, rounded, its disk concave; antennae I 5-jointed, the third joint longer than the second, strongly excised

Microstilba Förster

67. Mesonotum with 5 carinae Mesonotum without carinae

68. Marginal cell open along the front margin . Marginal cell closed along the front margin .

69. Scutellum normal, unarmed Scutellum abnormal, armed with two horns behind
Tropideucoela Ashmead

Disorygma Förster

7 I

70

Dicerataspis Ashmead 
70. Unknown ( 9 only known)

Triplasta Kieffer Pentaplasta Kieffer

Ectolyta Förster

7r. First joint of flagellum shorter than the fourth, the latter the stouter . $\quad 7^{2}$ First joint of flagellum not longer than the fourth, the following slightly and gradually increasing in length . . . . . Erisphazia Förster

72. Apex of wings entire not emarginate . . . . Psilosema Kieffer Apex of wings emarginate . . . . . Schizosema Kieffer

73. Front wings at apex emarginate or excised; apical abscissa of the submarginal vein stout, quadrate, at the most only a little longer than thick . 74 Front wings at apex entire, never emarginate or excised, although sometimes shortened and truncate; apical abscissa of the submarginal vein slender, not stout, always two or more times longer than thick

74. Marginal cell open along the front margin . . . . . . . $\quad 75$ Marginal cell closed along the front margin. . . Leptopelina Förster

75. Scutellum normal, not produced into a beak at apex . . . . ${ }_{76}$ Scutellum abnormal, produced at apex into a beak or horn

Rhynchacis Förster

76. First joint of the flagellum not or scarcely longer than the second, rarely curved, and hardly as thick as the second . . . . . . . 77

First joint of the flagellum a little longer than the second, stouter and usually slightly curved, the following joints cylindrical, usually three or more times longer than thick and gradually but imperceptibly increasing in length to the penultimate . . . . . . . . . . Kleidotoma Westwood

77. Joints of flagellum long, cylindrical, equal in length or very nearly, and at least four times as long as thick .

Joints of flagellum differently formed . $\quad . \quad$. $\quad . \quad$. $\quad . \quad$. 78

78. Flagellar joints $\mathrm{I}$ to 3 equal in length or very nearly, the first slightly curved, clavate, the apical joints not or rarely more than three times as long as thick

Pentacrita Förster

Flagellar joint I scarcely as long as the second or distinctly shorter, the following joints stouter, fully thrice as long as thick . Hexacola Förster Unknown .

Heptameris Förster

79. Wings abbreviated . $. \quad . \quad . \quad . \quad . \quad . \quad . \quad . \quad . \quad 80$

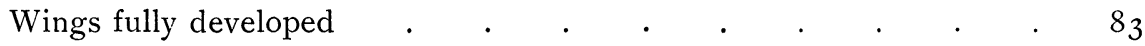

80. Metapleura bare or at most very sparsely pubescent . . . . . $8 \mathrm{I}$ Metapleura clothed with a dense pubescence

Marginal cell incomplete, the second abscissa of the radius wanting or very short .

. Glauraspidia Thomson 
Marginal cell completely formed, the first abscissa of the radius shorter than the second . . . . . . . Apistophyza Förster

8r. Wings reaching at least to the middle of the abdomen, and with a marginal cell . . . . . . . . . . . . . 82 Wings not reaching beyond the base of the abdomen, and without a marginal cell

Antennae 15 -jointed, the first joint of the flagellum distinctly longer than the second, excised, the following not quite twice as long as thick

Aphyoptera Förster

82. Wings shorter than the abdomen, the marginal cell closed

Agroscopa Förster Wings as long as the abdomen, the marginal cell open along the front margin, the first abscissa of the radius longer than the second

Aphiloptera Förster

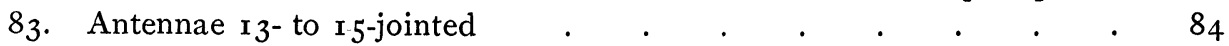

Antennae 16-jointed, very long, the flagellar joints long, cylindrical

Wings glabrous, the marginal cell closed Macrocereucoila Ashmead (Type M. longicornis Ashm.)

Wings pubescent, the marginal cell closed . . Episoda Förster

84. Antennae I 5-jointed . . . . . . . . . . 87

Antennae I3- $_{3}$ - 4 -jointed

Antennae 14-jointed

Antennae 13 -jointed

Flagellum long, filiform, the joints long, cylindrical, the first joint only about half as long as the second ; cup of scutellum large, rounded

Promiomoera Ashmead, gen. nov.

(Type P. filicornis Ashm.)

85. Marginal cell closed along the front margin . . . . . . $\quad$. 86 Marginal cell open along the front margin . . Idiomorpha Förster

86. Cup of scutellum large, rounded, the whole disc concave Miomoera Förster Cup of scutellum large oval the whole disc not concave, anteriorly flat, posteriorly with a fovea . . . . . Paramiomoera Ashmead

87. Marginal cell closed along the front margin . . . . . . $\quad .88$ Marginal cell open along the front margin . . . . . . Ior

88. Wings pubescent, the margins fringed or ciliated . . . . $\quad . \quad 89$ Wings bare, glabrous, without a marginal fringe

Antennae long, filiform, the joints cylindrical . Eucoila Westwood

89. First abscissa of the radius distinctly shorter than the second . . 90 First abscissa of the radius as long as the second 
First joint of the flagellum distinctly shorter than the second

Hypolethria Förster

First joint of the flagellum as long or nearly as long as the second

Rhoptromeris Förster

90. Scutellum normal, or at least not ending in a spine

Scutellum ending in a spine

9 I

91. First joint of the flagellum usually longer than the second, more rarely equal in length, or very slightly shorter

First joint of the flagellum very distinctly shorter than the second

Heptamerocera Ashmead

92. Scutellum normal, the cup not modified into a carina . . . . $\quad$. 93

Scutellum abnormal, the axillae acutely toothed posteriorly, the cup modified into a carina which is gradually dilated posteriorly, appearing tridentate

Trissodontaspis Ashmead

93. Head and thorax smooth and shining $\quad$. $\quad . \quad$. $\quad . \quad$. $\quad . \quad 94$

Head and thorax not smooth and shining, but finely coriaceous; scutellum with two large foveae at base, the cup narrowed ellipzoidal, connected with a carina anteriorly; antennae long, the joints long, cylindrical, the first joint of the flagellum not longer or thicker than the second, the eighth and beyond slightly shortening . . . . . Dieucoela Ashmead

94. First joint of the flagellum not greatly elongated, thickened, or strongly curved

First joint of the flagellum usually greatly elongated, much thickened and curved

Aglaotoma Förster

95. Marginal cell short nearly as wide as long, the second abscissa of the radius strongly curved outwardly; cup of scutellum very large . . . . $\quad 96$

Marginal cell not especially short, always much longer than wide; mesonotum

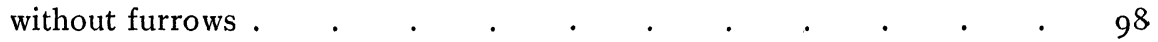

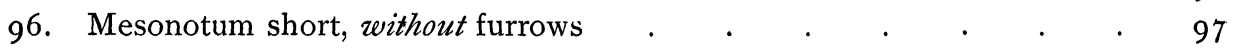

Mesonotum with two fine furrows abbreviated posteriorly and two very broad lateral impressions shortened anteriorly . . . Chrestosema Förster

97. Mesonotum with a very delicate median carina; cup of scutellum very large oval; first joint of the flagellum not longer than the second, the joints oblong oval, about thrice as long as thick . . . . Zaeucoela Ashmead, gen. nov.

(Type Z. unicarinata Ashm.)

Mesonotum without a median carina; cup of scutellum large rounded, the disk flat or slightly impressed; first joint of the flagellum longer than the second (or rarely shorter and slenderer), the following joints oval or moniliform hardly longer than thick or at most only about twice as long as thick, never thrice as long as thick . . . . . . . . Ganaspis Förster 


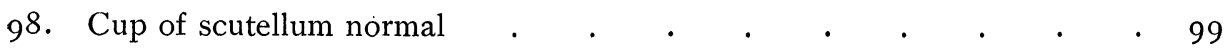
Cup of scutellum overlapping the apex of the scutellum Psichara Förster

99. First joint of the flagellum not longer than the second or on'y a little longer . . . . . . . . . . . . 100 First joint of the flagellum very distinctly longer than the second, the following joints from $2 \frac{1}{2}$ to 3 times as long as thick . Hexamerocera Kieffer ıо०. Flagellar joints long, cylindrical, four or more times longer than thick

Pseudeucoila Ashmead

Flagellar joints at the most thrice as long as thick or even shorter

Pentamerocera Ashmead ror. Marginal cell confluent with the costal cell, the apical abscissa of the submarginal vein wanting . . . . . . . . . . . . 102

Marginal cell not confluent with the costal cell, the apical abscissa of the submarginal vein always present $. \quad . \quad . \quad . \quad . \quad . \quad . \quad 103$ ro2. Second abscissa of the radius wanting or not extending to the costa, the marginal cell therefore open at apex . . . . . . . Adieris Förster

Second abscissa of the radius distinct, reaching the costa; first joint of the flagellum more than twice the length of the second; the second and following moniliform . . . . . . . . Piezobria Förster

r03. Cubitus in front wings always more or less present or distinct . . $\quad$ ro4 Cubitus in front wings obliterated or wanting . . . . . 106 r04. Wings pubescent, ciliate . . . . . . . . . 105 Wings bare, glabrous, not ciliate . . . . Lytosema Kieffer r05. Cup of scutellum narrowed, ellipzoidal; first joint of flagellum very long, slightly curved, as long as 2 and 3 united, joints beyond cylindrical

Pilinothrix Förster Cup of scutellum rather large oval or ovate; first joint of flagellum not longer than the second $\quad . \quad . \quad . \quad . \quad . \quad . \quad . \quad$ Cothonaspis Hartig ro6. Cup of scutellum normal or not ending in a spine . Trybliographa Förster Cup of scutellum abnormal, ending in a strong spine

Acantheucoela Ashmead I 07. Cup of scutellum not large, either ovate or ellipzoidal with a fovea posteriorly Cup of scutellum large broadly oval or rounded

First joint of the flagellum subclavate at least as long as the second

Diranchis Förster 

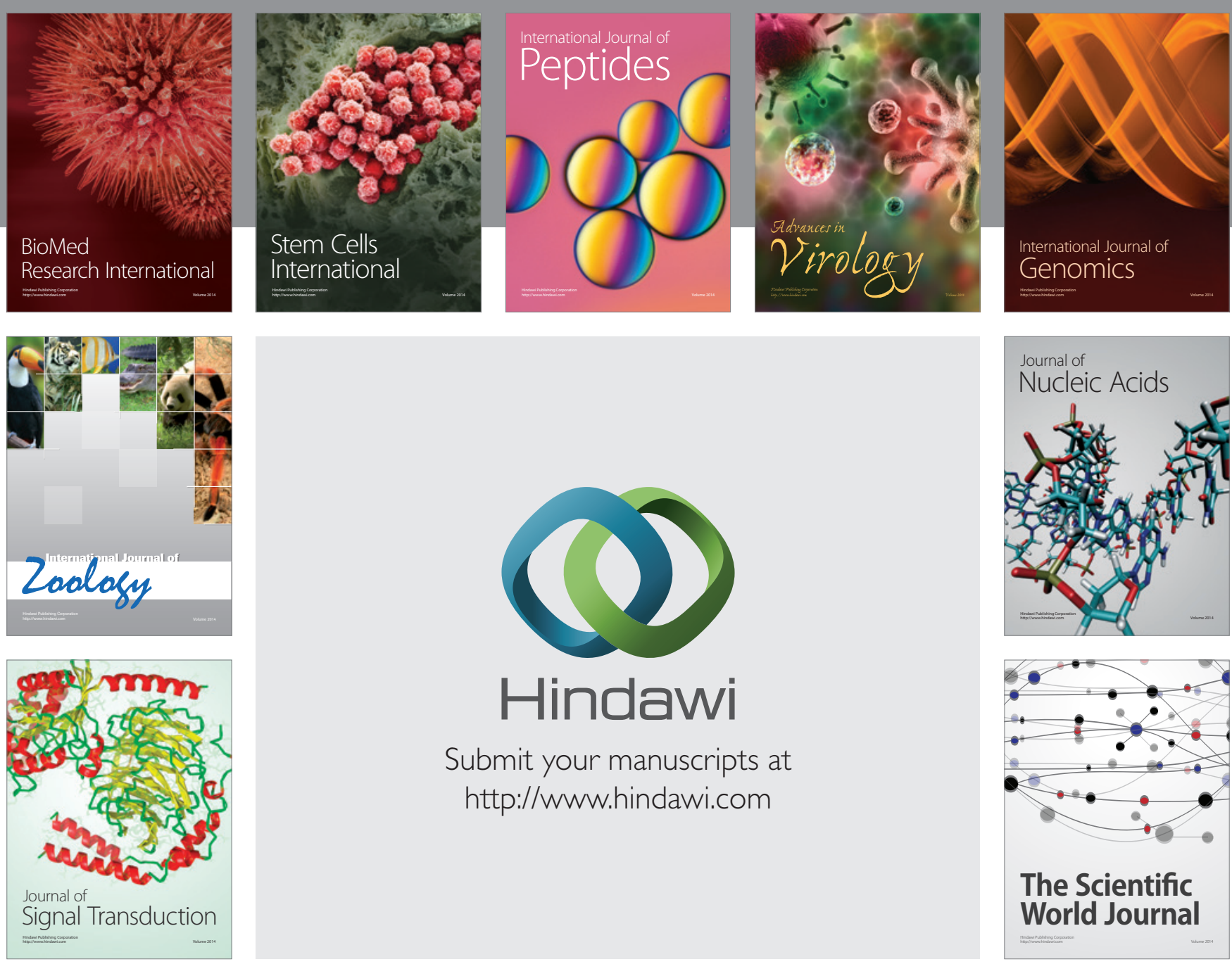

Submit your manuscripts at

http://www.hindawi.com
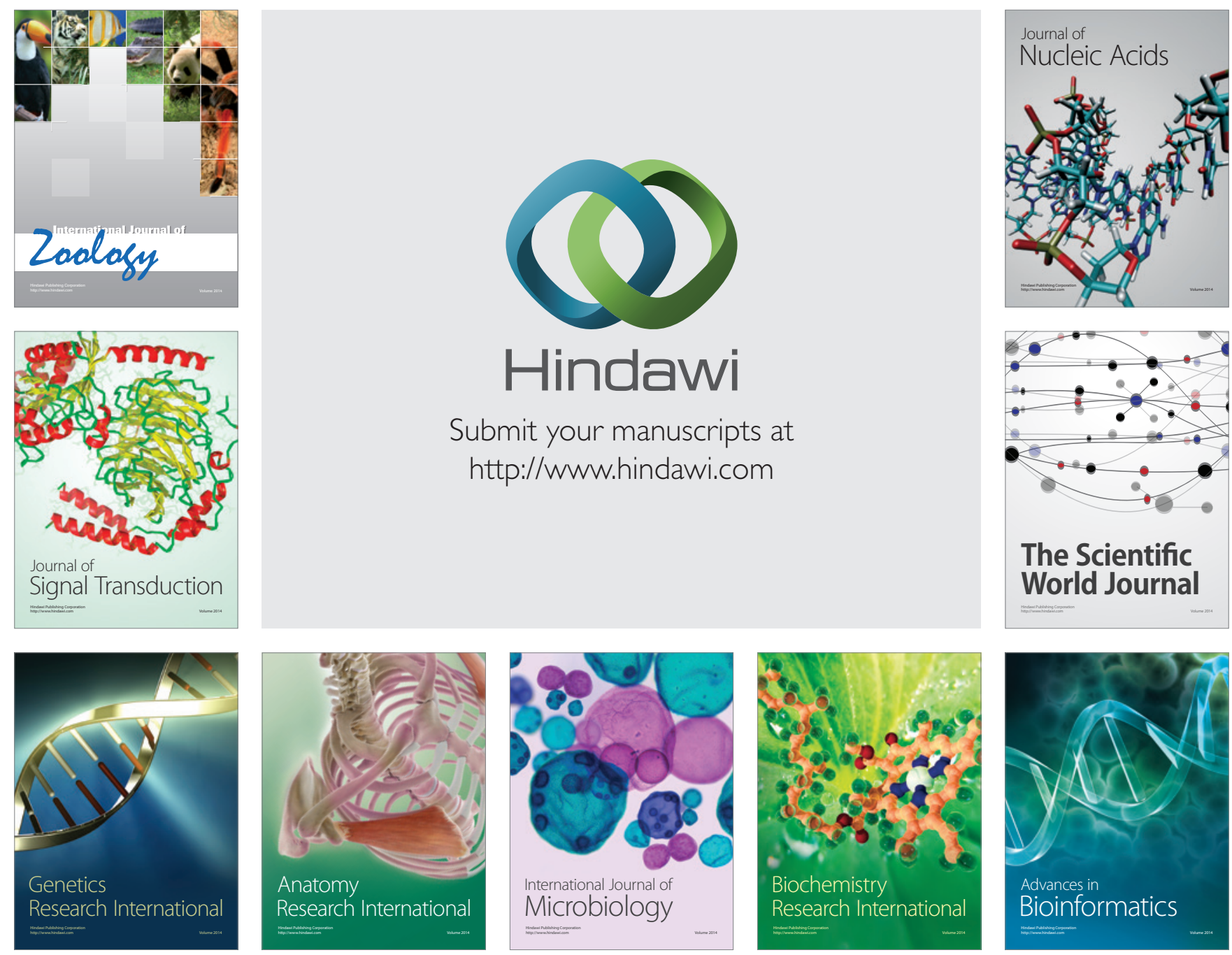

The Scientific World Journal
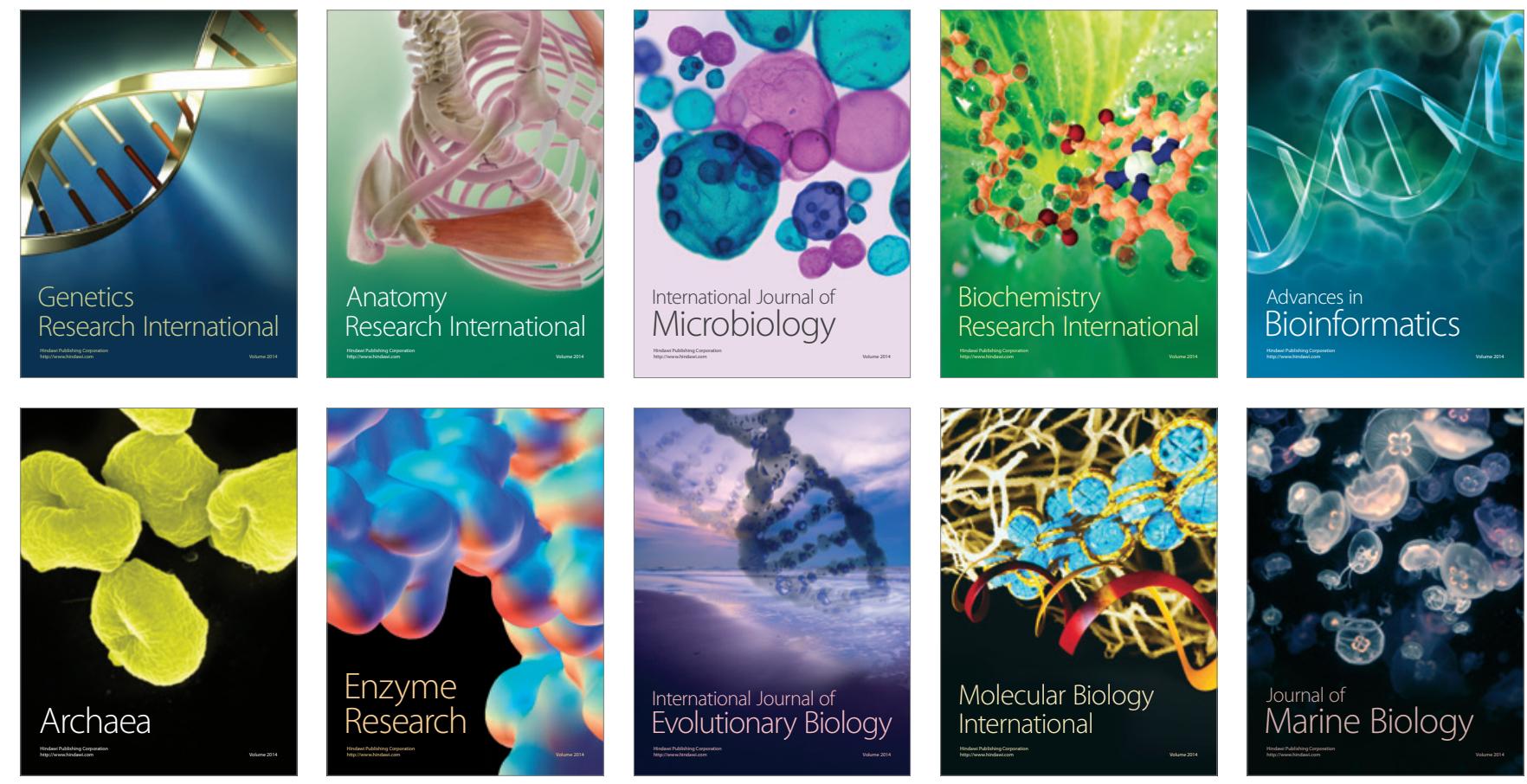